\title{
Performance Tasks and Socialization of Students with Broken Family
}

\author{
Jerald C. Moneva \\ Department of Education-Mandaue City Division \\ Mandaue City, Cebu, Philippines \\ Tel: +63908-927-3038_E-mail: freezingfire1979@gmail.com
}

Monique Bantasan

Jagobiao National High School

Mandaue City, Cebu, Philippines

Tel: +63908-662-1564 E-mail: moniquebantasan15@gmail.com

\author{
Ria M. Vertulfo \\ Department of Education Division of Cebu Province \\ Mandaue City, Cebu, Philippines \\ E-mail: ria.vertulfo@deped.gov.ph
}

Received: February 6, 2020 Accepted: March 25, 2020 Published: April 2, 2020

doi:10.5296/ijssr.v8i2.16789 URL: http://dx.doi.org/10.5296/ijssr.v8i2.16789

\begin{abstract}
Broken family leads to children being raised by single parents, stepparents or others not related to the biological parents. The study used a univariate likert scale among senior high school students in Jagobiao National High School. There are questions to gather the data. Firstly, students with broken family reported that they perform differently compared to the students with complete family. They do not have the confidence to stand out in class and even socializing the people around them. The findings of the study is statistically not significant between performance task and socialization of the students with broken family because the Cross tabulation presented that performance task does not affect the students socialization. Majority of the students perform well with a complete family rather than the broken ones. A number of students have fair confidence to socialize with other people. Other students with
\end{abstract}




\section{Macrothink}

International Journal of Social Science Research

ISSN 2327-5510 2020, Vol. 8, No. 2

incomplete family poorly perform their task and their socialization skills rated poor as well. Hence, most of the students with incomplete family satisfactory perform their task and their socialization skill rated as satisfactory also. The study accentuates that the two variables performance task and socialization of the students with broken family does not have a significant correlation.

Keywords: students, broken family, performance task, socialization 


\section{Introduction}

\subsection{Rationale}

Family consists of the parents and their offspring or a two or more people who share goals and values in life. It is important and something that should never be taken for granted, it is the people who you can count on no matter what.

In the modern stage of the family there are two kinds of families: the complete and the broken family. Broken family can affect the life of their children. It might be the reason that the children will be mislead. It is the one of the family factor why other children are getting rebellious in school and they cannot focus because of the problems they encountered at home. Individual's surrounding the learners with broken family need to take action in approaching them even asking for their well-being and concerned about the consequences they have experienced.

In Jagobiao National High School, it was observed that the students who have broken family tend to be problematic, easily got irritated and experiences anxiety at times. They do not have a peace of mind and cannot focus to their studies because of the problem they encountered at home. Students came from a broken family are different compared to the students who came from a complete family. They have an opposite action. Most of them are hiding themselves and emotion into their naughty actions. They want to socialize and gain more friends in which it served as their comfort zone. Most of the students who are products of a broken family are more rebellious because they want to get the attention of their parents and they also want to feel that they are important. They have lack of interest in learning because they easily get tempted to do bad habits. They are also very aggressive to the thing that they want to do. Some of them are doing badly which is influenced by their friends. Students lack affection from their parents. They want to gain attention from them. Hence, some of the students who came from a broken family used their family problems as their motivation in order for them to succeed in life. Few of the students were independent enough to take care to themselves while others do the opposite.

Moreover, individual came from a broken homes were mostly found in delinquent peer groups than those from unbroken families (Quenseel et al., 2002). Their approach in social aspect is different. They want someone to talk to and share their problems to them. Thus, some students who came from a broken family are less talkative than the other students because they much prefer to be alone. Socialization among students may become more distinctive when there is an emotion-specific approach (Weidmann \& Stein, 2003). Most of the students prefer outside activities than their home. Students who belong to broken family are unhappy. Somehow they used it as their inspiration to become a better person and to be stronger to face the reality, yet they don't want to happen to their future children to suffer what they been experiences in their life.

Consequently, the study intends to determine the relationship of between performance task and socialization of the students with broken family.

\subsection{Theoretical Background}

This study anchored on Dr. Murray Bowen's theory. The family system theory was published and developed the year 1913-1990. This provides a current framework for human behavior 
conceptualization and human problem management. It is a relationship theory. As for the proponent, Bowen considered that the functioning of people should be understood in the context of their interaction that the emotional functioning is closely interconnected with each others, with reciprocal effort (Bowen, 1913-1990).

Bowen developed the theory of family system from natural science understanding, evolutionary biology, and his family study. Bowen considers that the human family system. Like any other living type is part of nature and is controlled by relationship procedures of the system automatically entails compensatory modifications in order components of the framework. Bowen (1913-1990) established the 4 concept foundation. The anxiety, basic life, emotional system and last the family as an emotional unit (Bowen, 1913-1990)

Anxiety is seen in the functioning of people families and socialization as a significant variable. Bowen considers two types of anxiety the acute anxiety and chronic anxiety is about responding to the stress reaction of other people. (Bowen, 1913-1990)

Two basic life forces Bowen stipulates each organism of system is controlled by two life forces that counterbalance, the force towards unity and the force towards individuality. The strength towards unity drives needs for social support, love and affection. In seeking for the satisfaction of the need for unity, there is a tendency to expect oneself and others to be like and act alike, on behalf of others to sacrifice in order to obtain the approval of others to dominate others so that others act in accordance with one's own ideas. On the other side, motivate the need for selves striving to be unique and different. A highly functioning individual is able to stand on his or her own floor. (Bowen, 1913-1990)

Emotional system Bowen presented that the mental system governs much of human functioning. The feeling system is the emotional expression of cognition or consciousness that is not usually felt. The mental system is capable of understanding and communicating complex and abstract ideas.

The family as an emotional unit Bowen saw the family as an organism with characteristics that are higher than the sum of its individual components and that each component depends on each other emotionally. And emotional interdependence drives individual form fused relationship when anxiety is high. Bowen (1913-1990) proposed a systematic to relationship instead of seeing interaction as a cause and effort. They should look at each other's conditional behavioral impact. How are both that cause and effect of the interactional communication. It enables us to look at their condition behavioral impact. How is both that cause effect of the interactional communication? It enables us to look at each of us contribution in our dealings with others concentrating on our duties and self-change in order to impact change. Bowen considered it's beneficial to define the pattern established by families over the distinct generation to deal with anxiety and not just concentrates on the person identified then strategies foe invention can be created. In the student's future career preferences, it can be also influenced by their experiences it also a factor into behavioral actions that will occur. In relation to this, this study relates to the theory in which students with broken family tend to be anxious. Meanwhile two basic life forces relates to students socialization skills in which it is govern by a counter balancing life forces, the force towards togetherness. Were in togetherness drives the need for social support, affection and love and helps establishing a meaningful relationship with other people. 


\subsection{Statement of Purpose}

This study aims to assess the correlation of broken family attitude towards performance task and socialization with broken family.

\subsection{Review of Related Literature}

Broken family can be deal and at the same time, it can be stop from happening (Saika, 2017). Adolescents from complete families are more adoptable in respect of their personal and social adjustments levels than the students from broken families (Elmaci, 2006). One of the main factors that most of the broken families encounter is the economic support (Heijden \& Schmidt, 2007). Family break up affects the children in dealing problems because of the lack of attention coming from their parents (Qureshi, 2016). There is a significant variation of performance in school of students from a one-parent family and students from two-parent family (Uwaifo, 2012). There are unstable differences in the effects of broken homes between genders (Wells and Rankin, 1991). The individual who came from broken homes were mostly found in delinquent peer groups than those from unbroken families (Quensel et. al., 2002). One issue that is seen in broken family is that they have a higher degree of saving measures (Yusufoglu \& Kizmaz, 2016). The children who have divorced parents have the risks of getting pregnant without undergoing marriage especially the divorced happened during their mid-teenage life (Fagan, 1999). Significantly, family life is the root in which there is a creation of society, communities and especially our country (Wilkinson, 2013). Moreover, the income of two-parent families is greater than the families with single-parent (Zinsmeister, 1992).

Learning process is further fruitful, further effective styles if former expert were applied (Klein, Feldman, \& Zarur, 2002). Learners must enhance positive perspective in daily lives in order to support them in their academic success (Omoruyi, 2016). Student's performance in school is one of the most effective predictors of parent's expectation towards them (Yamamoto and Holloway, 2010). However parent- school involvement may not lead to the increase of reading performance and as much in mathematics (Hill \& Defreitas, 2003). Mother's for academic grades is positively associated to children's pre reading and pre math performance (Hill, 2015). Children academic performance in mathematics was seen as their task motivation in the early school career (Aunola, Leskinen, \& Nurmi, 2006). Face book usage is one of the activities that the students do with studying that may improve their academic performance (Kirschener \& Kanpinski, 2010). Academic resiliency is the output of temperamental and having a different motivational characteristics (Eccles, Vida, \& Barber, 2004). Student's academic performance relies on their socio-economic status (Okioga, 2013). Enhancing academic performance or motivation to comply complete assignments had no significant effect (Cavilla, 2017).

Socialization goals mediate between broader socio-cultural orientations (families) and parenting ethno theories concerning beliefs about good parenting (Kelter et al., 2006). It was revealed that the effects of family socialization on a person's developing emotional expression have longer impact (Halberstadt, 1986). Socialization in higher education can provide learners with an accumulative improvement for cognition (Goodman, Pascarella, \& Saichaei, 2010). Socialization in children with disabilities needs to imply acceptance, assimilation and reproduction of norms, values and attitudes (Zvoleyko, Kalashnikova, \& 
Kilimenko, 2016). Socialization of doctoral learners to the academic aspect has an association to learner point of view of department faculty encouragement for learner's participation in such activities (Weidman \& Stein, 2003). Socialization may become more distinctive when there is an adoptive emotion specific approach (Wong, McElwain, \& Italberstait, 2009). Environment of schools on students outcomes predominately focus on academic outcomes with little attention to the processes and outcomes from a social and emotional development perspective (Garibaldi \& Josias, 2015). Learners from rural areas have a higher negative attitude towards their classmates rather than the students from the semi-urban and urban areas (Papaoikonomou, 2017). Students with higher degree of socialization show the breadth cognitive interests (Bulaev,Koverkina, Soshenko, Shmyrev, \& Shmyrev, 2016). Learners who felt a strong belongingness are known to be social students (Basaran \& Demir, 2017).

\section{Research Method}

\subsection{Design}

The study used the descriptive correlation quantitative research design because the study takes into account the correlation of the broken family between the student's performance task and socialization. The design involves systematically collecting and using information from a specified population to describe the certain population characteristic. The design is regarded suitable for this research as the purpose of work is to gather information in order to describe the entire population. The study aims to determine the correlation between the broken family in performance task and the socialization of the students.

\subsection{Environment}

The research was conducted in Jagobiao National High school situated in Jagobiao, City of Mandaue. The senior high school department of Jagobiao National High school has a great way of strategy of teaching. They offer 5 academic tracks which were GAS, HUMSS, ABM, STEM, and TVL. The teachers are excellence when it comes in training their students. The students gain a lot of knowledge from the teachers. The teachers of Jagobiao National High school senior high department have a lot of achievements because of the quality of their teaching strategy.

\subsection{Respondents}

The research respondents would be selected in the students that came from a broken family and complete family. There were 6 males and 12 females in the ABM 11 class for a total of 18 respondents. There were 6 males and 10 females for a total of 16 respondents in the class of HUMSS. There were 7 males and 12 females for a total 19 respondents in the class of STEM 11. There were 6 males and 9 females for a total 15 respondents in the class of GAS 11. There were 8 males and 8 females for a total of 16 respondents in the class of HUMSS 12 . There were 7 males and 11 females for a total of 18 respondents in the class of GAS 12; all in all there were 102 respondents from grade 11 and 12 students.

\subsection{Data Gathering Procedure}

In each strand the researcher sent a letter to principal of the school and also the adviser for the approval to conduct a research using the questionnaire set. The researcher explains objectives and purpose of the research which the researcher distributed to the respondents. They were provided a maximum of 10 minutes to answer the questionnaire. It served as the basis for the 
study's assessment, interpretation, conclusion and also recommendation.

\section{Data Analysis and Discussion}

Table 1. Broken Family Performance Task

\begin{tabular}{lll}
\hline INDICATORS & Weighted Mean & Interpretation \\
\hline $\begin{array}{ll}\text { 1. I enjoy assignments and activities because they help me improve } \\
\text { my skills in every subject }\end{array}$ & 2.44 & Sometimes \\
2. I like to join extracurricular activities such as sports, performing & 2.47 & Sometimes \\
arts, clubs, etc. & \\
3. I like to participate oral recitation & 2.27 & Sometimes \\
$\begin{array}{l}\text { 4. I like to participate academic contest such as quiz bee } \\
\text { 5. I participate performance task to get a good grade }\end{array}$ & 1.99 & Sometimes \\
6. I actively participate in every activities & 2.78 & Often \\
7. I gain focus during my activities for me to have a great & 2.52 & Often \\
performance and high grades & 2.78 & Often \\
8. I enjoy every activities because it help me to improve my skills \\
$\begin{array}{l}\text { 9. I pay attention and listen carefully when the teacher gives an } \\
\text { instruction about the performance task }\end{array}$ & 2.64 & Often \\
$\begin{array}{l}\text { 10. I exert more effort in practicing my performance task } \\
\text { Overall Weighted Mean }\end{array}$ & 2.66 & Often \\
\hline
\end{tabular}

Scale: 1.00-1.75 (Never); 1.76-2.50 (Sometimes); 2.5-3.25 (Often); 3.26-4.00 (Always)

The table expresses the overall weighted mean and interpreted as often the first to the highest weighted mean was 2.78 and interpreted as often. It implies that students participate in performance task to get good grades. The second to the lowest weighted mean was 2.78 and interpreted as often. It indicates that students gain focus during activities for them to have a great performance and high grades the third to the highest weighted mean was 2.76 and interpreted as often. It signifies that students pay attention and listen carefully when the teacher gives an instruction about the performance task. In addition, the first to the lowest was 2.44 and interpreted as sometimes. It visualize that sometimes students enjoy assignments and activities because they help them to improve their skills in every subject. The second to the lowest was 2.27 and interpreted as sometimes. It reveals that student does not like to participate in oral recitation. The third to the lowest weighted mean was 1.99 and interpreted as sometimes. It shows that not all the time students like to participate in academic contest such as quiz bee. Students with complete family are significantly lower a depression scale averages than the students with broken family (Elamci, 2006). Students who have high income parents acquire more support than students with low income parents (Fagan, 1999). There is a significant difference between the academic students from single parent family and those fro, two-parent family (Uwaifo, 2012). 
Table 2. Performance Tasks

\begin{tabular}{llllll}
\hline & & Frequency & Percent & Valid Percent & Cumulative Percent \\
\hline Valid & Poor & 28 & 7.1 & 27.5 & 27.5 \\
& Fair & 52 & 13.2 & 51.0 & 78.4 \\
& Satisfactory & 22 & 5.6 & 21.6 & 100.0 \\
& Total & 102 & 25.8 & 100.0 & \\
Missing & System & 293 & 74.2 & & \\
Total & & 395 & 100.0 & & \\
\hline
\end{tabular}

The tables above shows that the highest frequency in performance task has 52 and it shows that majority of the students who have broken family fairly perform their task in school. While the second to the lowest frequency has 28 and it indicates that the students poorly performed a task sometimes. The lowest frequency has 22 and it signifies that some students with broken family satisfactory perform a task despite of the situation they have.

In contrary, students with complete family are significantly lower a depression scale averages than the students with broken family (Elamci, 2006). Students who have high income parents acquire more support than students with low income parents (Fagan, 1999). There is a significant difference between the academic students from single parent family and those from two-parent family (Uwaifo, 2012).

Table 3. Broken Family: Socialization

\begin{tabular}{|c|c|c|}
\hline INDICATORS & Weighted Mean & Interpretation \\
\hline 1. I am confident when I speak in front of my classmates & 2.20 & Sometimes \\
\hline $\begin{array}{l}\text { 2. when speaking, I change my speaking style depending } \\
\text { on the audience being addressed }\end{array}$ & 2.29 & Sometimes \\
\hline $\begin{array}{l}\text { 3. I am confident that body language helps communicate } \\
\text { my intended message }\end{array}$ & 2.49 & Sometimes \\
\hline 4. I can easily communicate with others & 2.53 & Often \\
\hline $\begin{array}{l}\text { 5. I develop and maintain supportive relationship with } \\
\text { others }\end{array}$ & 2.61 & Often \\
\hline $\begin{array}{l}\text { 6. I directly speak to others about who I am, what I feel } \\
\text { and what I want }\end{array}$ & 2.40 & Sometimes \\
\hline $\begin{array}{l}\text { 7. I have the ability to make friends and create valuable } \\
\text { relationship in a new place }\end{array}$ & 2.63 & Often \\
\hline $\begin{array}{l}\text { 8. I communicate my anger or upsets without blaming } \\
\text { others }\end{array}$ & 2.54 & Often \\
\hline 9. I am open to being with people & 2.59 & Often \\
\hline $\begin{array}{l}\text { 10. I am open to understanding people with different } \\
\text { backgrounds }\end{array}$ & 2.68 & Often \\
\hline Overall Weighted Mean & 2.50 & Sometimes \\
\hline
\end{tabular}




\section{Macrothink}

The table visualize the overall weighted mean was 2.50 and interpreted as sometimes. The first to the highest weighted mean was 2.68 and interpreted as often. It indicates that students are open to understanding people with different backgrounds. The second to the highest weighted mean was 2.63 and interpreted as often. It implies that the students have the ability to make friends and create valuable relationship in a new place. The third to the highest weighted mean was 2.61 and interpreted as often. It signifies that students develop and maintain supportive relationship with others. Furthermore, the first to the lowest weighted mean was 2.40 and interpreted as sometimes. It signifies that sometimes students directly speak to others about who they are, what they feel and what they want. The second to the lowest weighted mean was 2.29 and interpreted as sometimes. It implies that scarcely when speaking, students change their speaking style depending on the audience being addressed. The third to the lowest weighted mean was 2.20 and interpreted as sometimes. It indicates that students are not much confident when they speak in front of their classmate. The students who have a strong case of belongings are also social students (Basaran \& Demir, 2017). In terms of socialization, behavior and activities of an individual become more sustainable gain motives and determine human behavior and focus (Bulaev et.al, 2016).

Table 4. Socialization

\begin{tabular}{llllll}
\hline & & Frequency & Percent & Valid Percent & Cumulative Percent \\
\hline Valid & poor & 26 & 6.6 & 25.5 & 25.5 \\
& fair & 59 & 14.9 & 57.8 & 83.3 \\
& satisfactory & 17 & 4.3 & 16.7 & 100.0 \\
& Total & 102 & 25.8 & 100.0 & \\
Missing & System & 293 & 74.2 & & \\
Total & & 395 & 100.0 & & \\
\hline
\end{tabular}

The table above shows that the highest frequency in socialization of the students with broken family has 59 and it shows that most of the students with broken family fairly socialize other people in school. While the second to the lowest frequency has 26 and it indicates that some students poorly socialize and communicate the people around them. The lowest frequency has 17 and it signifies that some students with broken family satisfactory socialize other people through communication even if they came from broken families.

Students socialize more with their peers (Weidman \& Stein, 2003). The students who have a strong case of belongings are also social students (Basaran \& Demir, 2017). In terms of socialization, behavior and activities of an individual become more sustainable gain motives and determine human behavior and focus (Bulaev et.al, 2016). 
Table 5. Broken Family: Performance Task and Socialization

\begin{tabular}{|c|c|c|c|c|}
\hline Lambda Nominal by Nominal & Value & Asymp. Std. Error ${ }^{\mathrm{a}}$ & Approx. $\mathrm{T}^{\mathrm{b}}$ & Approx. Sig \\
\hline Symmetric & .161 & .079 & 1.924 & .054 \\
\hline Socialization Dependent & .116 & .100 & 1.098 & .272 \\
\hline Performance Tasks Dependent & .200 & .072 & 2.580 & .010 \\
\hline \multicolumn{5}{|c|}{ a. Not assuming the null hypothesis. } \\
\hline \multicolumn{5}{|c|}{ b. Using the asymptotic standard error assuming the null hypothesis. } \\
\hline \multicolumn{5}{|c|}{ c. Based on chi-square approximation } \\
\hline
\end{tabular}

The table above revealed that student's performance task in school does not have a significant association with their socialization to the people around them. Since the computed p-value (0.54) is greater than significant alpha (0.5). It means that student's performance task does not affect their socialization in school. The students improved their performance and moved to the intermediate level (Garilbaldi \& Josias, 2015). Students socialize more with their peers (Bulaev et al, 2016). Socialization involves the correlation of information obtained through personal social experience and the formation of own attitude to this information (Weidman \& Stein, 2003).

\section{Findings}

The study aims to assess the level of attitude of students towards their performance task in school wherein majority of them reported that their parents support and help them in terms of school activities sometimes.

On one hand, student's level of attitude towards socialization in school rated as seldom among the respondents. They do not like to gain attentions from their teachers and classmates.

Significantly, the study revealed that broken family, student's performance task and their socialization in school have a significant association.

\section{Conclusion}

The study signifies that the student's family background affects differently to their academic performance and socialization in school. Majority of the respondents who have a complete family perform well in school. They want to get higher grades and constantly join different activities offered by the school unlike the respondents who have a broken family. However, socialization among students from a complete family emphasizes confidence in dealing other learners and educators. On the other hand, phase of socialization of the students from broken families were opposite from mentioned above. They usually feel uncomfortable when communicating their teachers and classmates. Family relationship plays vital role on the student's development mentally and socially. It is very important that the students learn on how to deal situational problems and create good solutions. Students are seen to have a high 
level of performance when it comes to academic tasks. They are motivated despite of the situation just to gain high achievements in school.

\section{Recommendation}

The researcher recommends the students to join activities that will enhance their confidence to perform better in school. Teachers should help the students to boost their confidence in communicating the people around them and in performing academic tasks. Students should find a way on how they motivate themselves in performing well in school and dealing family problems.

\section{References}

Aunola, K., Leskinin, E., \& Nurmi, J.-E. (2006). Developmental dynamics between mathematical performance, task motivation, and teachers' goals during the transition to primary school. The British Psychological Society, 76, 21-40. https://doi.org/10.1348/000709905X51608

Basaran, Z., \& Demir, A. (2017). The relationship between the students' socialization and sense of belonging who attended university's spring festivals. Universal Journal of Educational Research, 5(12), 89-95. https://doi.org/10.13189/ujer.2017.051314

Bulaev, V. A. et al. (2016). Socialization of student's youth as a factor of development and social renewal of the contemporary society: by experience of the Russian state social university. International Review of Management and Marketing, 6(3), 53-64. Retrieved from https://www.econjournals.com/index.php/irmm/article/view/2185

Cavilla, D. (2017). The effects of student reflection on academic performance and motivation. Special Collection-Student Diversity, 1-13. https://doi.org/10.1177/2158244017733790

Eccles, J. S., Barber, B. L., \& Vida, M. N. (2004). The relation of early adolescents college plans and both academic ability and task-value beliefs to subsequent college enrollment. The Journal of Early Adolescence, 24(1), 63-77. https://doi.org/10.1177/0272431603260919

Elmaci, F. (2006). The role of social support on depression and adjustment levels of adolescents having broken and unbroken families. Educational Sciences: Theory and Practices, 6(2), 421-431. Retrieved from https://www.questia.com/library/journal/1P3-1370472281/the-role-of-social-support-on-depre ssion-and-adjustment

Fagan, P. F. (1999). How broken families rob children of their chances for future prosperity. The Heritage Foundation Backgrounder, 4-24. Retrieved from https://www.heritage.org/marriage-and-family/report/how-broken-families-rob-children-theirchances-future-prosperity

Garibaldi, M., \& Josias, L. (2015). Designing schools to support socialization processes of students. Procedia Manufacturing, 3, 1587-1584. https://doi.org/10.1016/j.promfg.2015.07.446 
Goodman, K. M. et al. (2010). The impact of college student socialization, social class, and race on need for cognition. New Directions for Institutional Research, 99-108. https://doi.org/10.1002/ir.324

Halberstadt, A. G. (1986). Family socialization of emotional expression and nonverbal communication styles and skills. Journal of Personality and Social Psychology, 51(4), 827-836. https://doi.org/10.1037/0022-3514.51.4.827

Heijden, M. V., \& Schmidt, A. (2007). Broken families: economic resources and social networks of women who head families. The History of the Family, 223-232. https://doi.org/10.1016/j.hisfam.2007.12.006

Hill, N. E. (2001). Parenting and academic socialization as they relate to school readiness: the roles of ethnicity and family income. Journal of Educational Psychology, 93(4), 686-697. https://doi.org/10.1037//0022-0663.93.4.686

Hill, N. E., \& Defreitas, S. C. (2003). Parents-school involvement and school performance: mediated pathways among socioeconomically comparable African and Euro-American families. Journal of Educational Psychology, 95(1), 74-83. https://doi.org/10.1037/0022-0663.95.1.74

Keller, H. et al. (2006). Cultural models, socialization goals, and parenting ethno theories. Journal of Cross-Cultural Psychology, 155-172. https://doi.org/10.1177/0022022105284494

Kirschner, P. A., \& Karpinski, A. C. (2010). Face book and academic performance. Computers in Human Behavior, 26, 1237-1245. https://doi.org/10.1016/j.chb.2010.03.024

Klein, P. S., Feldman, R., \& Zarur, S. (2002). Mediatation in a sibling context: the relations of older siblings' mediating behavior and younger siblings' task performance. Wiley Inter Science, 11, 321-333. https://doi.org/10.1002/icd.261

Okioga, C. K. (2013). The impact of students' socio-economic background on academic performance in universities, a case of students in kisii university college. American International Journal of Social Science, 2(2), 38-46. Retrieved from https://www.semanticscholar.org/paper/The-Impact-of-Students-\%E2\%80\%99-Socio-econom ic-Background-Okioga/79f02e15669825ae8cb78613c46bd4abf786867b

Omoruyi, I. V. (2014). Influence of broken homes on academic performance and personality development of the adolescents in Lagos state metropolis. European Journal of Educational and Development Psychology, 2(2), 10-23. Retrieved from http://kubanni.abu.edu.ng/jspui/bitstream/123456789/10317/1/INFLUENCE\%20OF\%20BR OKEN\%20HOME\%20ON\%20ACADEMIC\%20PERFORMANCE\%20AMONG\%20PRIM ARY\%20SCHOOL\%20PUPILS\%20IN\%20PAIKORO\%2C\%20NIGER\%20STATE\%2C\%20 NIGERIA.pdf

Papaoikonomou, A. (2017). The impact of political socialization on students' behavior: empirical research in schools of central Macedonia in Greece. International Journal of Educational Research Review. https://doi.org/10.24331/ijere.327468 
Quensel, S. et al. (2002). Broken home or drug using peers: "significant relations"? Journal of Drug Issues, 468-489. Retrieved from https://www.researchgate.net/publication/270671137_Broken_Home_or_Drug_using_Peers_ Significant_Relations

Qureshi, A. (2015). Socio-psychological effects of broken families on socialization and academic performance among the children of Multan division. Innovative Space of Scientific Research Journals, 22(1), 146-152. Retrieved from http://www.issr-journals.org/links/papers.php?journal=ijisr\&application=pdf\&article=IJISR-1 6-019-06

Saikia, R. (2017). Broken family: its causes and effects on the development of children. International Journal of Applied Research, 3(2), 445-448. Retrieved from http://www.allresearchjournal.com/archives/2017/vol3issue2/PartG/3-2-106-798.pdf

Uwaifo, V. O. (2012). The effects of family structures on the academic performance of Nigerian university students. Global Journal of Human Social Science, 12(5). Retrieved from https://globaljournals.org/GJHSS_Volume12/7-The-Effects-of-Family-Structures.pdf

Weidman, J. C., \& Stein, E. L. (2003). Socialization of doctoral students to academic norms. Research in Higher Education, 44(6), 641-655. https://doi.org/10.1023/A:1026123508335

Wells, E. L., \& Rankin, J. H. (1991). Families and delinquency: a meta-analysis of the impact of the broken homes. Social Problems, 38 (1), 71-93. https://doi.org/10.2307/800639

Wilkinson, E. (2013). Learning to love again: "broken families", citizenship and the state promotion of couple dom. Geoforum. https://doi.org/10.1016/j.geoforum.2013.02.012

Wong, M., Halberstadt, A. G. \& McElwain, N. L. (2009). Parent, family, and child characteristics: associations with mother-and father-reported emotion socialization practices. Journal of Family Psychology, 23(4), 452-463. https://doi.org/10.1037/a0015552

Yamamoto, Y., \& Holloway, S. D. (2010). Parental expectations and children's academic performance in sociocultural context. Educational Psychology Review, 22, 189-214. https://doi.org/10.1007/s10648-010-9121-z

Zinsmeister, K. (1992). Parental responsibility and the future of the American family. Cornell Law Review, 77, 1005-1011. Retrieved from https://scholarship.law.cornell.edu/cgi/viewcontent.cgi?article $=3543 \&$ context $=\mathrm{clr}$

Zvoleyko, E. V., Kalashnioka, S. A., \& Klimenko, T. K. (2016). Socialization of students with disabilities in an inclusive educational environment. International Journal of Environmental \& Science Education, 11(14), 6469-6481. Retrieved from https://files.eric.ed.gov/fulltext/EJ1115873.pdf

\section{Glossary}

Broken family: is the split or separation of family members due to a variety of reasons. This leads to children being raised by single parents, stepparents or others not related to the biological parents. 


\section{Macrothink}

International Journal of Social Science Research

ISSN 2327-5510 2020, Vol. 8, No. 2

Performance task: is any learning activity or assessment that asks students to perform to demonstrate their knowledge, understanding and proficiency despite of their family situation at home.

Socialization: is the student's way of making friends, going out to their own shelves and dealing other people.

\section{Appendix}

Part 1: Socialization

Name:

Age:

Grade \& Strand:

Gender:

Instruction: Read the indicators carefully and check your answer honestly

Always (4)Often (3)Sometimes (2) Never (1)

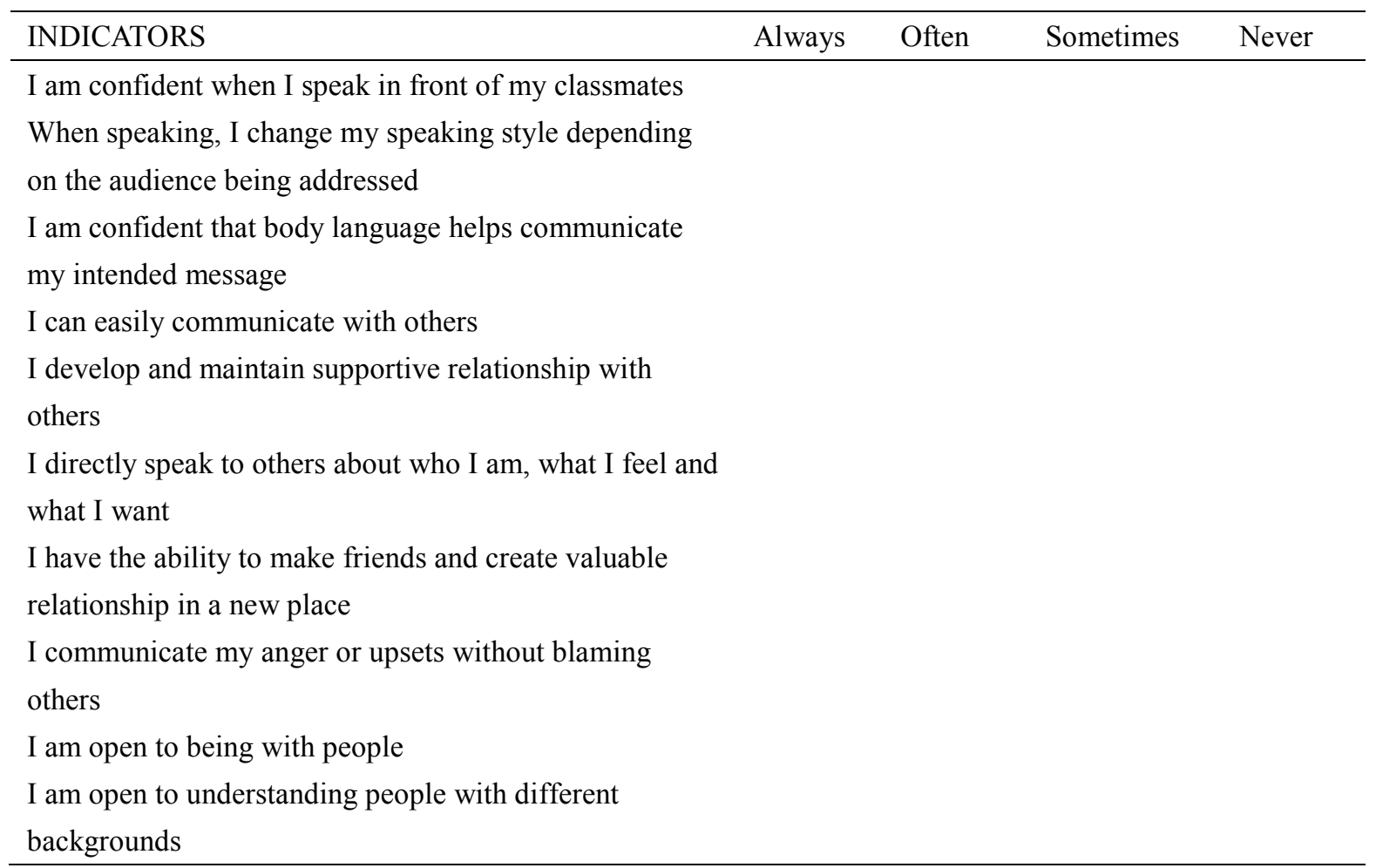

\section{Copyrights}

Copyright for this article is retained by the author(s), with first publication rights granted to the journal.

This is an open-access article distributed under the terms and conditions of the Creative Commons Attribution license (http://creativecommons.org/licenses/by/4.0/). 